\title{
Sources of Potential Fungi Generated Biogenic Nanoparticles for the Control of Diseases Transmitting Mosquitoes: A Review
}

\author{
Siva Kamalakannan ${ }^{1, *(\mathbb{D})}$, Kalimuthu Kovendan ${ }^{2(\mathbb{D})}$, Vellingiri Balachandar ${ }^{3(\mathbb{D})}$, \\ Karamtothu Gopi Naik ${ }^{1}$ (D), Arun Chauhan ${ }^{\text {(D) }}$ \\ 1 National Centre for Disease Control, Ministry of Health and Family Welfare, 22-Sham Nath Marg, Civil Line, Delhi- \\ 110054, India \\ 2 Division of Vector Biology and Control, Department of Zoology, Annamalai University, Annamalainagar-608002, \\ Chidambaram, Tamil Nadu, India; gokulsuryah@gmail.com (K.K.); \\ 3 Stem Cell Division, Department of Human Genetics and Molecular Biology, Bharathiar University, Coimbatore-641046, \\ Tamil Nadu, India; geneticbala@gmail.com (V.B.); \\ * Correspondence: kamal410@yahoo.com (S.K.);
}

Received: 31.05.2021; Revised: 5.072021; Accepted: 9.07.2021; Published: 5.09.2021

\begin{abstract}
Vector mosquitoes are diseases transmitting malaria, filarial, dengue, and Japanese encephalitis are an enormous burden to public people worldwide. There is no proper vaccine for those diseases; even though malaria is significant, challenges are still waiting for successful management. Recently, fungi and fungi-derived products control mosquito larvae, pupae, and adults better than compared to plants or other microorganisms. The using fungi such as Aspergillus sp., Beauveria bassiana, Metarhizium anisopliae, Verticillium lecanii are more virulent for controlling mosquito vectors, Aedes aegypti, Anopheles stephensi, Culex quinquefasciatus. The synthesis of silver, gold, zinc, and copper nanoparticles from those fungi has been getting good biological sources for significant reduction of mosquito larval and pupal populations. Fungal-based nanoparticles are highly effective and biorational insecticide for the control of vector populations. In this review, we discussed various sources of fungi that can be synthesized from different nanoparticles to control disease-transmitting mosquito vectors.
\end{abstract}

Keywords: microorganism; fungi; nanoparticles; mosquito control; biorational insecticide.

(C) 2021 by the authors. This article is an open-access article distributed under the terms and conditions of the Creative Commons Attribution (CC BY) license (https://creativecommons.org/licenses/by/4.0/).

\section{Introduction}

Mosquitoes carrying pathogens or parasites are endemics in the human population worldwide [1-4]. The threatened mosquito species are an enormous burden to the public and transmit malaria, filarial, yellow fever, Japanese encephalitis, dengue, and zika virus [5-8]. Presently, no right vaccine is available for the treatment of malaria. In this scenario, all other mosquito-borne diseases are challenging issues for successful control and management. Recently, nanoparticles paid more attention to the prevention and control of mosquito-borne diseases.

In this above-said fact, recently, nanoparticles are considered a potential candidate for mosquito control to prevent mosquito-borne diseases [9]. Nanoparticles have reached a goal with the benefit of increasing their efficacy, controlled delivery to the target species, and also long-lasting ability. Using eco-friendly nanoparticles can help control the environmental 
problem, perhaps using chemical insecticides as larvicides [9-15]. Currently, silver nanoparticles are widely used for mosquito vector control $[16,17,18]$.

Recently, fungal toxin or fungal-derived products based nanoparticles are effective in controlling aquatic mosquito larvae and pupae. Therefore, fungal nanoparticle syntheses are an effective bio-control weapon instead of using conventional insecticide[19,20]. Nonetheless, the nanoparticle dispersion must be purified to eliminate fungal residues and impurities, which can be achieved using simple filtration, membrane filtration, gel filtration, dialysis, and ultracentrifugation [21]. The size of the nanoparticles depends on the synthesis conditions such as fungus species, temperature, $\mathrm{pH}$, and dispersion medium, as well as the presence of capping on the nanoparticles [22]. The color of the dispersion is also directly related to the surface plasmon resonance, which varies according to the size and absorbance of the nanoparticles [23]. The synthesis and reduction of biometal could boost the development of a non-toxic, clean, and green approach to the environment for the better production of nanoparticles [24, 25]. Various microbial synthesized nanoparticles are obtained from enzymes, peptides, proteins, electron shuttle quinones, and exopolysaccharides and their mechanism of synthesis by various bioreducing agents [26]. Microbes like bacteria, fungi, and yeast [27-29], are useful production of metal nanoparticles under normal room temperature. The fungiFusarium oxysporum [30,31], Aspergillus fumigates [32], and Verticillium species [33] are used for the production of metal nanoparticles. According to $\mathrm{Li}$ et al., [43], $10 \mathrm{~min}$ synthesis of Phytophthora infestans fungus nanoparticles. Similarly, the larvicidal potential of fungus Cochliobolus lunatus against larvae of A. aegypti and An. stephensi were reported previously [35]. The fungus synthesized silver and gold nanoparticles are effectively control A. aegypti larvae [36,37]. The present review evaluates the larvicidal potential of synthesized varying metal nanoparticles using fungias, a better source for the control of mosquito larvae and pupae in the environment because of their fungal chitinolytic activity and nanoparticle reducing agents [38].

The use of conventional insecticides have disadvantages; toxic chemical generate form the waste leads to an environmental hazard. Recently increasing green approaches for nanoparticle synthesis have more attention than conventional methods [39,40]. The desirable size and morphology form bacteria, yeast, and fungi have been done [41]. Clean and non-toxic nanoparticle production has environmentally acceptable [42]. Fungi have higher quantities of extracellular proteins found, which contribute to nanoparticles become stable [43-45]. The good biomass production of fungi are more advantages [46] than other sources like plants; it is more suitable for mass production and syntheses $[47,48]$.

Recently, physical and chemical methods of nanoparticles synthesis from Fusarium oxysporum [49], Aspergillus fumigates, Verticillium species, Chrysosporium tropicum [50,51], Cochliobolus lunatus [52], and Puccinia graminis [53]. Highly stable AgNPs are significant control of mosquito larval and pupae. The size of nanoparticles up to $100 \mathrm{~mm}$ and size, distribution, and morphology were considered [54]. The synthesized and control of nanoparticles from microorganisms are potential for eliminating vector and vector-borne diseases $[55,56]$. Since the past, plants, fungi, bacteria, and viruses have utilized low cost, energy-efficient, and non-toxic to the environment [57].

\section{Synthesis of Fungus Mediated Silver Nanoparticles}

Fungal species produced bioactive proteins, which are used right from agriculture to the pharmaceutical industry [58-60]. The microbial bioactive compounds have been developed 
and are alternative to the conventional insecticide [61]. The fungal metabolites have highly toxic to the aquatic mosquito and are low in other organisms. The nanoparticles are synthesized various from silver, gold, zinc, copper; palladium has paid greater attention because of its physical, chemical, optical, electromagnetic, and mechanical properties [62,63]. Fungi produced known 6400 bioactive protein [64], and its cultivation is large scale production $[65,66,67]$. Fungi-produced mycelia contain a large amount of enzymes and proteins $[68,69]$. There were two types of synthesis nanoparticle from fungi, intracellular and extracellular. Intracellular synthesis, metal precursor added to the mycelia and internalized with biomass. The time needed for the required synthesis of nanoparticles and then followed by centrifugation, filtration through disrupting to get a release of nanoparticles [70-72].

Extracellular synthesis, metal precursor added to the fungal filtrate contain only fungal protein and enzyme, the result of the formation of nanoparticles [73-76]. The better syntheses of nanoparticles from the fungi are simple, and membrane filtration, gel filtration, or ultra centrifugations are used to synthesize nanoparticles [77-79] better. The fungal secondary metabolites could be the control of mosquito larvae and pupae. The fungal synthesized nanoparticles are effective and virulent for the alternative for the synthetic insecticide and pollution-free environment [80].

\subsection{Synthesis of metal nanoparticles.}

Silver nanoparticles vary from other inorganic chemicals because silver is a widely used metal due to its physical and chemical properties [81]. Silver nanoparticles are highly stable, have high thermal, electrical conductivity, chemical stability, catalytic activity. AgNPs properties rank are topper list $[82,83,84]$. AgNPs require Ag precursor, reducing, stabilizing agents. Silver is a reducing agent for many microorganisms as well as plant sources $[85,86]$. Similarly, other nanoparticles like zinc size range $50-120 \mathrm{~nm}$. The range indicates extracellularly sulfate reduced to sulfide due to sulfate reductase enzyme. Pbs nanoparticles by Torulopsis when exposed to aqueous $\mathrm{Pb}$ ions [87]. Fungi, Aspergillus synthesized lead nanoparticles have been better bioremediation and management [88]. The gold nanoparticles synthesized from fungi are recently reviewed, and their resistance and oxidation good be reliable; yellow and red color referred to large and small gold nanoparticles. The respecting varying morphology could be stabilizing substances like ascorbic acid and citrate [89]. Stabilization can achieve by polyvinyl alcohol [90].

The protein and enzyme on the surface of the fungi could be trapped because of gold ions [91]. The varying sources of gold nanoparticles have different properties. $\mathrm{AuCl}$ or $\mathrm{AuCl}_{3}$ follows both intra and extracellular pathways that require one electron to give gold nanoparticles, whereas, $\mathrm{AuCl}_{3}$ requires giving three electrons for occur reduction in three steps [92]. Gold nanoparticles from the fungus, Cyclindrocladium floridanum were demonstrated by Narayanan and Sakthivel [93]. Mukherjee [94] reported that Verticillum sp. Synthesized gold nanoparticles. Soni and Prakash [88] reported for green synthesis of gold nanoparticles from Aspergillus niger. The color changes occur its absorption at 530nm (Table 1). They also reported gold nanoparticles are toxic to An. stephensi, Cx. quinquefasciatus and A. aegypti larvae (Table 2).

Nanoparticles from copper are relatively a novel approach and using microorganism for the nanoparticle synthesis are a better achievement of nanobiology field [95]. The nanoparticles are living in the cell organelles, and their shape and size depend on the biological reduction of metal ions [96]. Fusarium oxysporium synthesize copper nanoparticles range from 
93-115nm at ambient temperature [97,98]. Copper nanoparticles synthesized from Aspergillus species extracellularly [99]. Copper has a spread spectrum of biocidal activities, and have several studies done with copper had remarkable antibacterial activity at the nanoscale level [100]. Copper has suitable biomedical activity, and it seems to be essential for living organisms [101].
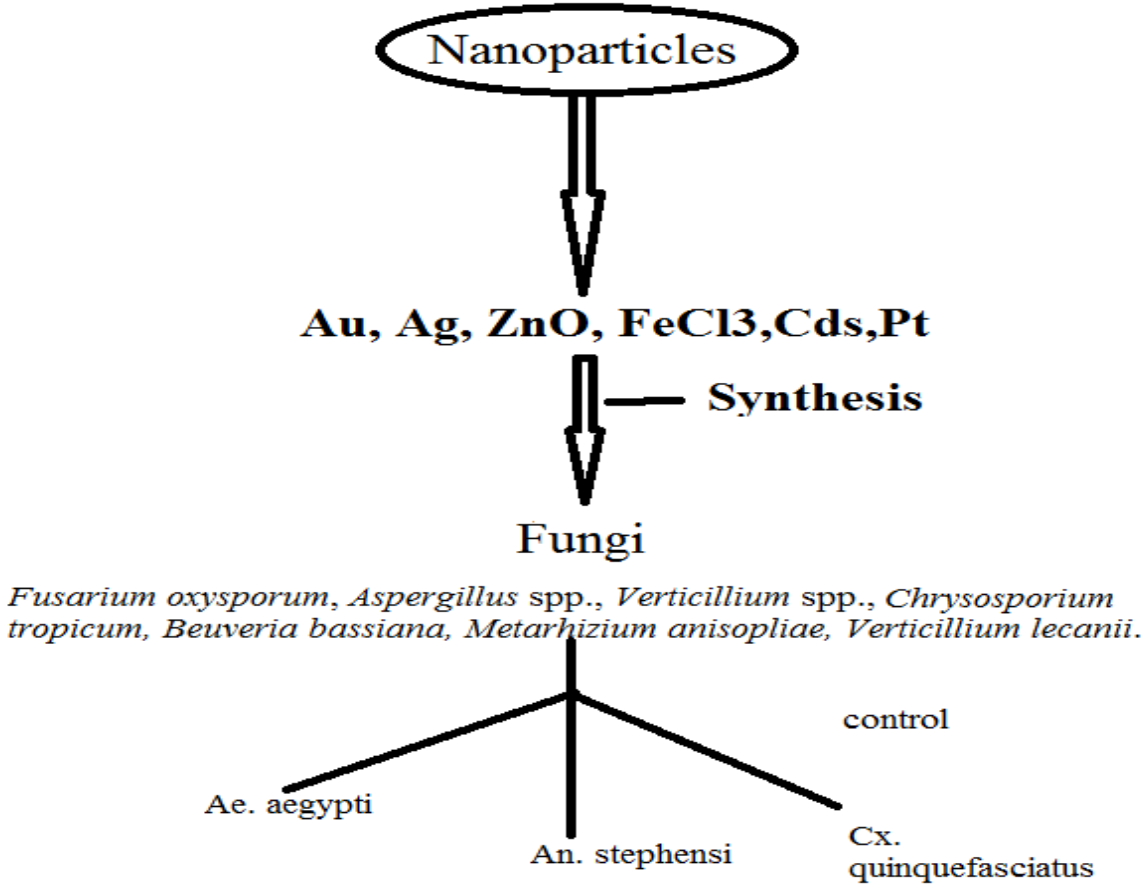

Figure 1. Various metal nanoparticles synthesis from fungi against vectors of mosquitoes.

\section{Fungus Nanoparticles for the Control of Mosquito Vectors}

\subsection{Aspergillus spp.}

Entomopathogenic fungi were found to be effective against mosquito larvae. Fungi contain enzymes and proteins as reducing agents for the synthesis of nanoparticles; they can be y used to synthesize metal nanoparticles. Fungi have a huge amount of protein than comparatively less in bacteria; therefore, converting metal salts to metal nanoparticles is very easy and fast [102]. The extracellular synthesis of silver nanoparticles by Aspergillus species, A. fumigates, A. clavatus, A.niger, and A. flavus (Fig. 1) and its nitrate reductase activity was reported by Kamiar Zomorodian [103]. In addition, primary fungal metabolites produce low molecular weight, often biologically active compounds known as secondary metabolites are usually produced by common biosynthetic pathways, often related to morphological development [104].

\subsection{Aspergillus niger.}

A. niger is a keratinophilic, filamentous ascomycete and group of saprophytic molds. Generally, conidia can grow up to 6-47 and $\mathrm{Ph} 1.4-9.8$. This fungus is used to produce citric acids, amylases, lipases, cellulases, xylanases, and proteases to remove heavy metal ions from wastewaters [105]. A. niger contains anthraquinone compounds responsible for reducing and capping agents. A. niger has better larvicidal and pupicidal activity [106]. A. niger nanoparticles are respective larvicidal activity and for environmentally safer side for maintaining ecosystem [107]. The enzyme reductase from A. niger reduced silver ions to 
AgNPs [108]. A. niger also produced extracellular lipase and purified fungal filtrate, which has a lethal effect on An. stephensi, Cx. quinquefasciatus and A. aegypti. Moreover, the presence of mycotoxin "Ochratoxin" in A. niger can be a fast metabolite for controlling adult mosquitoes.

\subsection{Aspergillus flavus.}

Fungus, A. flavus is a sporophyte haploid filamentous found globally and abundant in the temperate region. It's grown at $37^{\circ} \mathrm{C}$ with distinct spores and yellow color; a long stalk supporting vesicle is found [109]. A. flavus synthesis of nanoparticles either extracellular or intracellular by the mycelia extracts [110]. The extracellular synthesis of A. flavuswas also reported [111]. The green methods of silver nanoparticles are characterized; AgNPs prepared silver nitrate precursor, reducing agent, and stabilizer. Nanoparticles formed initially by $33 \mathrm{kDa}$ protein and followed by a protein (cysteine and free amino acid groups) electrostatic attraction can stabilize the nanoparticle as forming a capping agent [112].

\subsection{Aspergillus fumigatous.}

A. fumigatous rapid biosynthesis have formed silver nanoparticles [113,114] by potential extracellular synthesis. AgNPs using cell-free filtrate are rapid and suitable for largescale mass production [115]. The most efficient species of A. fumigatous is the highest nitrate reductase activity and produced a higher amount of nanoparticles, which is higher monodispersed than in other species [116]. The synthesized and characterized zinc oxide and zinc sulfate nanoparticles using A. fumigatous [117]. Shahzad et al.[118] synthesis of nanoparticles using Aspergillus fumigatus BTCB10, obtaining a size of $322.8 \mathrm{~nm}$ at $25^{\circ} \mathrm{C}$ and increasing size as the temperature was increased, reaching $1073.45 \mathrm{~nm}$ at $55^{\circ} \mathrm{C}$. Nanoparticles are attributed to the aggregation of nanoparticles at a higher temperature.

\subsection{Aspergillus terreus.}

A.terreus is widespread, and it's found all around the world, mostly cultivated in forest soil [119]. It plays an important role in nanoparticles formation and its reducing and capping agent of fungi synthesized AgNPs. The coenzyme NADH is widespread and found that the organism is involved in the redox reaction and used to reduce agents. The reductase enzyme released by A. tereus might be a synthesis of nanoparticles. NADH acts as an electron carrier; silver ions obtained electrons through NADH. NADH is a key factor in synthesizing AgNPs from the fungiA. terreus [120].

\subsection{Metarhizium anisopliae.}

M. anisopliae is found in soil-borne fungal pathogen of terrestrial insects, offers an environmentally friendly alternative to chemicals for the control of mosquitoes. M. anisopliaeis widely used to control larval and adult stages of Aedes, Anopheles, and Culex mosquitoes species $[121,122,123]$. M. anisopliae strain has been developed to control a wide variety of terrestrial arthropods, including pests of agro-forests crops and vectors of the human pathogen [124,125]. Larval and pupae of $C x$. pipiens were treated with $M$. anisopliae mediated AgNPs at different times and different concentrations. The larvae of $C x$. pipiens show $100 \%$ mortality to the prepared AgNPs after/h, whereas the pupae of $C x$. pipiens were less liable to the novel 
AgNPs. Synthesis nanoparticles from $M$. anisopliae can be used as a greener method for a safe environment for vector control [126].

Table 1. Synthesized metal nanoparticles of their varying size and shape fabricated from fungal species.

\begin{tabular}{l|l|l|l|c} 
Fungi & Nanoparticles & Size $(\mathbf{n m})$ & Shape & References \\
\hline A. clavatus & $\mathrm{Au}$ & $24.4 \pm 11$ & Triangular, spherical, and hexagonal & {$[91]$} \\
\hline A. flavus & $\mathrm{Ag}$ & 8.92 & spherical & {$[107]$} \\
\hline A. fumigates & $\mathrm{ZnO}$ & $1.2-6.8$ & Spherical and hexagonal & {$[136]$} \\
\hline A. oryzae & $\mathrm{FeCl}_{3}$ & $10-24.6$ & Spherical & {$[137]$} \\
\hline C. albicans & $\mathrm{Au}$ & 5 & Monodispersed spherical & {$[40]$} \\
\hline C. glabrata & $\mathrm{CdS}$ & $20 \AA, 29 \AA$ & Hexamer & {$[138]$} \\
\hline F. oxysporum & $\mathrm{Pt}$ & $70-180$ & $\begin{array}{l}\text { Rectangular, triangular, spherical, } \\
\text { and aggregates }\end{array}$ & {$[139]$} \\
\hline P.brevicompactum & $\mathrm{Au}$ & $10-60$ & Spherical, triangular and hexagonal & {$[140]$} \\
\hline P. jadinii & $\mathrm{Au}$ & $<100$ & Spherical & {$[33]$} \\
\hline Verticillium sp. & $\mathrm{Au}$ & $20 \pm 8$ & Spherical & {$[94]$} \\
\hline T.asperellum & $\mathrm{Ag}$ & $13-18$ & Nanocrystalline & {$[141]$} \\
\hline T. koningii & $\mathrm{Au}$ & $30-40$ & Small spheres to polygons & {$[142]$} \\
\hline P.chrysosporium & $\mathrm{Au}$ & $10-100$ & Spherical & {$[91]$} \\
\hline C. tropicum & $\mathrm{Ag}$ & $20-50$ & Spherical & {$[143]$} \\
\hline C. keratinophilum & $\mathrm{Ag}$ & $24-51$ & Spherical & {$[143]$} \\
\hline F. oxysporum & $\mathrm{Ag}$ & $20-40$ & Spherical & {$[143]$} \\
\hline A. niger & $\mathrm{Ag}$ & $20-70$ & Spherical & {$[143]$} \\
\hline V. lecanii & $\mathrm{Ag}$ & $20-50$ & Spherical & {$[143]$} \\
\hline M. anisopliae & $\mathrm{Ag}$ & $190-110$ & Spherical & {$[127]$} \\
\hline P. verucosum & $\mathrm{Ag}$ & $3-24$ & Spherical & {$[135]$}
\end{tabular}

Table 2. Various nanoparticles synthesized from fungus against the vector of mosquitoes.

\begin{tabular}{l|l|l|l|l} 
Fungi & Mosquito sp. & Nanoparticles & Size $(\mathbf{n m})$ & References \\
\hline C. tropicum & A. aegypti & $\mathrm{Ag}, \mathrm{Au}$ & $2-15 \& 20-50$ & {$[95,109,51]$} \\
\hline C. Lunatus & A. aegypti\&An. stephensi & $\mathrm{Ag}$ & $3-21$ & {$[136]$} \\
\hline C. tropicum & $\begin{array}{l}\text { C.quinquefasciatus \&An. } \\
\text { stephensi }\end{array}$ & $\mathrm{Au}$ & $20-50 \& 2-15$ & {$[95,109,51]$} \\
\hline A. flavus & C.quinquefasciatus & $\mathrm{Ag}$ & $2-10$ & {$[137]$} \\
\hline M.anisopliae & An. culicifacies & $\mathrm{Ag}$ & $20-24$ & {$[138]$} \\
\hline B. bassiana & A. aegypti & $\mathrm{Ag}$ & 20 & {$[139]$} \\
\hline C. tropicum & $\begin{array}{l}\text { C.quinquefasciatus \&An. } \\
\text { stephensi }\end{array}$ & $\mathrm{Ag} \& \mathrm{Au}$ & $20-50 \& 2-15$ & {$[95,109,51]$} \\
\hline A. niger & C. quinquefasciatus & $\mathrm{Ag}$ & $20-70$ & {$[140]$} \\
\hline P. verucosum & C.quinquefasciatus & $\mathrm{Ag}$ & $3-24$ & {$[135]$} \\
\hline C. keratinophilum & $\begin{array}{l}\text { C.quinquefasciatus\&An. } \\
\text { stephensi }\end{array}$ & $\mathrm{Ag}$ & $24-51$ & {$[143]$} \\
\hline F. oxysporum & $\begin{array}{l}\text { C. quinquefasciatus \&An. } \\
\text { stephensi. }\end{array}$ & $\mathrm{Ag}$ & $20-40$ & {$[143]$} \\
\hline V. lecanii & $\begin{array}{l}\text { C. quinquefasciatus\&An. } \\
\text { stephensi }\end{array}$ & $\mathrm{Ag}$ & $20-50$ & {$[143]$}
\end{tabular}

\subsection{Beauveria bassiana.}

Entomopathogenic fungi B. bassiana belong to the order Hypocreales (Ascomycota), which have a worldwide distribution and are naturally found in soil flora [127]. B. bassiana is a cosmopolitan that can inhabit a wide range of environments, including soil, insects, and plants. The fungus can live as a saprophyte in the soil, an endophyte in plants, or an entomopathogen affecting a wide range of arthropods [128]. Mycosynthesis of AgNPs using B. bassiana and its mosquitocidal properties against different larval instars were tested Aedes aegypti, Anopheles stephensi, and Culex quinquefasciatus. B.bassiana mediated silver nanoparticles are comparatively rapid and reliable cost. Antibacterial therapy in modern medicine $B$. bassiana synthesized silver nanoparticles would be more appropriate for environmentally safer insecticide for controlling mosquitoes (Table 2) [129]. 
3.8. Verticillium lecanii.

$V$. lecanii is one of the most common and important entomophagous Hyphomycetes fungi that occurred on coccids, aphids, thrips, Diptera, Homoptera, Hymenoptera, Lepidoptera, mites, and in all the climatic regions. Other important substrates for $V$. lecanii are rusts and other fungi. It has also been isolated from oak leaf litter, ash and birch, tea leaves, barley seed, baker's yeast, beet seed, and bursting corn kernels [130,131]. V. lecanii can grow on both living and dead materials [132]. It can produce conidia on solid media; in contrast, $V$. lecanii assumes a semi-yeast morphology in liquid media [133]. V. lecanii synthesized NPs were formed fairly uniform with spherical shape. Investigated the effect of $V$. lecanii synthesized AgNPs and AuNPs against the larvae and pupae of A. stephensi, C. quinquefasciatus, and A. aegypti. The larvae and pupae were found highly susceptible to the synthesized AgNPs than the AuNPs. The larvae of $C$. quinquefasciatus and A. aegypti were found to be more susceptible to the AgNPs, and AuNPs synthesized using V. lecanii compared with the larvae of An. stephensi (Table 2). This approach suggests that this rapid synthesis of fungus nanoparticles would be useful for developing a biological process for mosquito control [134].

\section{Conclusions}

Green synthesis of nanoparticles using fungi is an environmentally benign and renewable source for an effective reducing agent that could be utilized for a clean, non-toxic, and environmentally acceptable metal nanoparticle production. Many species of fungi have been utilized in nanotechnology for nanoparticle production, including Fusarium oxysporum, Aspergillus spp., Verticillium spp., and Chrysosporium tropicum, Beuveria bassiana, Metarhizium anisopliae, Verticillium lecanii, etc. The fungus nanoparticles formed are highly stable and significant for mosquito larvicide. Nanoparticles, generally considered as particles with a size of up to $100 \mathrm{~mm}$, exhibit completely new or improved properties compared to the larger particles of the bulk material that they are composed of based on specific characteristics such as size, distribution, and morphology. This present review demonstrated the fungus nanoparticles potential mosquito control agent for rapid synthesis, is cost-effective, and could be reliable sources. Synthesis of nanoparticles using microorganisms can potentially eliminate vector-borne disease problems by making the nanoparticles more bio-compatible.

\section{Funding}

This research received no external funding.

\section{Acknowledgments}

We thanks to the Head of the Department in Zoology, Bharathiar University, Coimbatore641046, Tamil Nadu for review the entire manuscript and support.

\section{Conflicts of Interest}

The authors declare no conflict of interest.

\section{References}

1. Mehlhorn, H. Encyclopedia of Parasitology. fourth ed.Springer, New York. 2015; pp. 893. 
2. Mehlhorn, H.; Al-Rasheid, K.A.; Al-Quraishy, S.; Abdel-Ghaffar, F. Research and increase of expertise in arachno-entomology are urgently needed. Parasitol. Res. 2012, 110, 259-265, https://doi.org/10.1007/s00436-011-2480-7.

3. Bonizzoni, M.; Gasperi, G.; Chen, X.; James, A. The invasive mosquito species Aedes albopictus: current knowledge and future perspectives. Trends Parasitol. 2013, 29, 460-468, https://doi.org/10.1016/j.pt.2013.07.003.

4. Benelli, G. Plant-mediated biosynthesis of nanoparticles as an emerging tool against mosquitoes of medical and veterinary importance: a review. Parasitol. Res. 2016a, 115, 23-34, https://doi.org/10.1007/s00436-0154800-9.

5. Benelli, G.; Mehlhorn, H. Declining malaria, rising dengue and Zika virus: insights for mosquito vector control. Parasitol. Res. 2016, 115, 1747-1754, https://doi.org/10.1007/s00436-016-4971-z.

6. Jensen M.; Mehlhorn, H. Seventy-five years of Resochin in the fight against malaria. Parasitol. Res. 2009, 105, 609-627, https://doi.org/10.1007/s00436-009-1524-8.

7. Pastula, D.M.; Smith, D.E.; Beckham, J.D.; Tyler, K.L. Four emerging arboviral diseases in North America: Jamestown Canyon, Powassan, chikungunya and Zika virus diseases. J. Neurovirol. 2016, 22, 257-260, https://doi.org/10.1007/s13365-016-0428-5.

8. Saxena, S.K.; Elahi, A.; Gadugu, S.; Prasad, A.K. Zika virus outbreak: an overview of the experimental therapeutics and treatment. Virus Dis. 2016, 27, 111-115, https://doi.org/10.1007/s13337-016-0307-y.

9. Sultana, N.; Raul, PK.; Goswami, D.; Das, B.; Gogoi HK.; Raju, P.S. Nanoweapon: control of mosquito breeding using carbon-dot-silver nanohybrid as a biolarvicide. Environ. Chem. Lett. 2018, 16, 1017-1023, https://doi.org/10.1007/s10311-018-0712-0.

10. Chandran, SP.; Chaudhary, M.; Pasricha, R.; Ahmad, A.; Sastry, M. Synthesis of gold nanotriangles and silver nanoparticles using Aloe vera plant extract. Biotechnol. Prog. 2006, 22, 577-583, https://doi.org/10.1021/bp0501423.

11. Ledwith, D.M.; Whelan, A.M.; Kelly, J.M. A rapid, straight-forward method for controlling the morphology of stable silver nanoparticles. J. Mater. Chem. 2007, 17, 2459-2464, https://doi.org/10.1039/b702141k.

12. Brichkin, SB.; Spirin, MG.; Nikolenko, LM.; Nikolenko, DY.; Gak, V.Y. The use of reversed micelles for the synthesis of nanoparticles. High Energy Chem. 2008, 42, 516-521, https://doi.org/10.1134/S0018143908070035.

13. Mafune, F.; Kohno, J.; Takeda, Y.; Kondow, T.; Sawabe, H. Structure and Stability of Silver Nanoparticles in Aqueous Solution Produced by Laser Ablation. J. Phys. Chem. B.2008, 104, 8333-8337, https://doi.org/10.1021/jp001803b.

14. Malynych, S.Z.; Chumanov, G. Vacuum deposition of silver island films on chemically modified surfaces. $J$. Vac. Sci. Technol. A. 2003, 21, 723-727, https://doi.org/10.1116/1.1570837.

15. Patil, C.D.; Patil, S.V.; Borase, H.P.; Salunke, B.K.; Salunkhe, R.B. Larvicidal activity of silver nanoparticles synthesized using Plumeria rubra plant latex against Aedes aegypti and Anopheles stephensi. Parasitol. Res. 2012, 110, 1815-1822, https://doi.org/10.1007/s00436-011-2704-x.

16. Velayutham, K.; Rahuman, A.A.; Rajakumar, G.; Roopan, S.M.; Elango, G.; Kamaraj, C.; Marimuthu, S.; Santhoshkumar, T.; Iyappan, M.; Siva, C. Larvicidal activity of green synthesized silver nanoparticles using bark aqueous extract of Ficus racemosa against Culex quinquefasciatus and Culex gelidus. Asian Pac. J. Trop. Med. 2013, 6, 95-101, https://doi.org/10.1016/S1995-7645(13)60002-4.

17. Muthukumaran, U.; Govindaraja, M.; Rajeswary, M. Mosquito larvicidal potential of silver nanoparticles synthesized using Chomelia asiatica (Rubiaceae) against Anopheles stephensi, Aedes aegypti, and Culex quinquefasciatus (Diptera: Culicidae). Parasitol. Res. 2015, 114, 989-999, https://doi.org/10.1007/s00436014-4265-2.

18. Afsar Ali, S.; Mazher,A.; Abdullah, A.; Muhammad, O.R.; Ammad, A.M.; Humna, A.; Affifa, Q. Toxicity effect of green synthesized nanoparticle silver nitrate (AgNO3) and titanium oxide (TiO2) against mosquitoes. GSC Biological and Pharmaceutical Sciences, 2021, 14, 016021,https://doi.org/10.30574/gscbps.2021.14.2.0022.

19. Wang, X.; Xu, J.; Sun, T.; Ali, S. Synthesis of Cordyceps fumosorosea-Biochar Nanoparticles and Their Effects on Growth and Survival of Bemisia tabaci (Gennadius). Front. Microbiol.2021, 12, https://doi.org/10.3389/fmicb.2021.630220.

20. Xu, J.; Zhang, K.H.; Cuthbertson, A.G.S.; Du, C.L.; Ali, S. Toxicity and biological effects of Beauveria brongniartii $\mathrm{Fe} 0$ nanoparticles against Spodoptera litura (Fabricus). Insects2020, 11,https://doi.org/10.3390/insects11120895.

21. Yahyaei, B.; Pourali, P. One step conjugation of some chemotherapeutic drugs to the biologically produced gold nanoparticles and assessment of their anticancer effects. Sci. Rep. 2019, 9, 1876, https://doi.org/10.1038/s41598-019-46602-0.

22. Lee, S.H.; Jun, B.H. Silver nanoparticles: synthesis and application for nanomedicine. Int. J. Mol. Sci. 2019 , 20,https://doi.org/10.3390/ijms20040865.

23. Bhangale, H.G.; Bachhav, S.G.; Nerkar, D.M.; Sarode, K.M.; Patil, D.R. Study on optical properties of green synthesized silver nanoparticles for surface plasmon resonance. J. Nanosci. Tech. 2019, 5, 658-661, https://doi.org/10.30799/jnst.230.19050203. 
24. Bahrulolum, H.; Nooraei, S.; Javanshir, N.; Tarrahimofrad, H.; Mirbagheri, V.S.; Easton, A.J.; Ahmadian, G. Green synthesis of metal nanoparticles using microorganisms and their application in the agrifood sector. Journal of Nanobiotechnology 2021, 19,https://doi.org/10.1186/s12951-021-00834-3.

25. Roy, A.; Bulut, O.; Some, S.; Kumar Mandal, A.; Deniz Yilmaz, M. Green synthesis of silver nanoparticles: biomolecule-nanoparticle organizations targeting antimicrobial activity. RSC Adv. 2019, 9, 2673-2702, https://doi.org/10.1039/c8ra08982e.

26. Geeta Gahlawat, G.; Choudhury, A.R. A review on the biosynthesis of metal and metal salt nanoparticles by microbes. RSC Adv. 2019, 9, 12944-12967, https://doi.org/10.1039/C8RA10483B.

27. Song, J.Y.; Kim, B.S. Rapid biological synthesis of silver nanoparticles using plant leaf extracts. Bioprocess Biosyst. Eng. 2009, 32, 79-84, https://doi.org/10.1007/s00449-008-0224-6.

28. Nair, R.; Varghese, S.H.; Nair, B.G.; Maekawa, T.; Yoshida, Y.; Kumar, D.S. Nanoparticulate material delivery to plants. Plant Sci. 2010, 179, 154-163, https://doi.org/10.1016/j.plantsci.2010.04.012.

29. Rico, C.M.; Majumdar, S.; Duarte-Gardea, M.; Peralta-Videa, J.R.; Gardea-Torresdey, J.L. Interaction of nanoparticles with edible plants and their possible implications in the food chain. J. Agric. Food Chem. 2011, 59, 3485-3498, https://doi.org/10.1021/jf104517j.

30. Durán, N.; Marcato, P.D.; Durán, M.; Yadav, A.; Gade A.; Rai, M. Mechanistic aspects in the biogenic synthesis of extracellular metal nanoparticles by peptide, bacteria, fungi, and plants. Appl. Microbiol. Biotechnol. 2011, 90, 1609-1624, https://doi.org/10.1007/s00253-011-3249-8.

31. Husen, A.; Siddiqi, K.S. Carbon and fullerene nanomaterials in plant system. J. Nanobiotechnol. 2014a, 12, 16, https://doi.org/10.1186/1477-3155-12-16.

32. Husen, A.; Siddiqi, K.S. Phytosynthesis of nanoparticles: concept, controversy and application. Nano Res. Lett. 2014b; 9, https://doi.org/10.1186/1556-276X-9-229.

33. Gericke, M.; Pinches, A. Microbial production of gold nanoparticles. Gold Bull. 2006, 39, 22-28, https://doi.org/10.1007/BF03215529.

34. Li, X.; Xu, H.; Chen, Z.S.; Chen, G. Biosynthesis of nanoparticles by microorganisms and their applications. J. Nanomater. 2011, 16, https://doi.org/10.1155/2011/270974.

35. Iravani, S. Bacteria in nanoparticle synthesis: current status and future prospects. Int. Schol. Res. Notic. 2004, 18, https://doi.org/10.1155/2014/359316.

36. Soni, N.; Prakash, S. Factors Affecting the Geometry of Silver Nanoparticles Synthesis in Chrysosporium Tropicum and Fusarium Oxysporum. Curr. Res. Nanotechnol. 2011, 2, 112-121, https://doi.org/10.3844/ajnsp.2011.112.121.

37. Guilger-Casagrande, M.; de Lima, R.Synthesis of Silver Nanoparticles Mediated by Fungi: A Review. Front. Bioeng. Biotechnol.2019, 7, https://doi.org/10.3389/fbioe.2019.00287.

38. Santos, T.S.; Passos, E.M.d.; Seabra, M.G.d.J.; Souto, E.B.; Severino, P.; Mendonça, M.d.C.Entomopathogenic Fungi Biomass Production and Extracellular Biosynthesis of Silver Nanoparticles for Bioinsecticide Action. Appl. Sci. 2021, 11, https://doi.org/10.3390/app11062465.

39. Iravani, S. Bacteria in nanoparticle synthesis: current status and future prospects. Int. Schol. Res. Notic. 2004, 18, https://doi.org/10.1155/2014/359316.

40. Ahmed, S.; Ahmad, M.; Swami, B.L.; Ikram, S. A review on plants extract mediated synthesis of silver nanoparticles for antimicrobial applications: a green expertise. J. Adv. Res. 2016, 7, 17-28, https://doi.org/10.1016/j.jare.2015.02.007.

41. Azmath, P.; Baker, S.; Rakshith, D.; Satish, S. Mycosynthesis of silver nanoparticles bearing antibacterial activity. Saudi Pharm. J. 2016, 24, 140-146, https://doi.org/10.1016/j.jsps.2015.01.008.

42. Banu, A.N.; Balasubramanian, C. Mycosynthesis of silver nanoparticles using Beauveria bassiana against dengue vector, Aedes aegypti (Diptera:Culicidae). Parasitol. Res. 2014b, 113, 2869-77, https://doi.org/10.1007/s00436-014-3948-z.

43. Balaji, D.S.; Basavaraja, S.; Deshpande, R.; Mahesh, D.B.; Prabhakar, B.K.; Venkataraman, A. Extracellular biosynthesis of functionalized silver nanoparticles by strains of Cladosporium cladosporioides fungus. Colloids Surf B Biointerfaces. 2009, 68, 88-92, https://doi.org/10.1016/j.colsurfb.2008.09.022.

44. Du, L.; Xu, Q.; Huang, M., Xian, L.; Feng, J.X. Synthesis of small silver nanoparticles under light radiation by fungus Penicillium oxalicum and its application for the catalytic reduction of methylene blue. Mater. Chem. Phys. 2015, 160, 40-47, https://doi.org/10.1016/j.matchemphys.2015.04.003.

45. Netala, V.R.; Bethu, M.S.; Pushpalatah, B.; Baki, V.B.; Aishwarya, S.; Rao, J.V.; Tartte, V. Biogenesis of silver nanoparticles using endophytic fungus Pestalotiopsis microspora and evaluation of their antioxidant and anticancer activities. Int. J. Nanomed. 2016, 11, 5683-5696, https://doi.org/10.2147/IJN.S112857.

46. Gade, A.K.; Bonde, P.; Ingle, A.P.; Marcato, P.D.; Durán, N.; Rai, M.K. Exploitation of Aspergillus niger for synthesis of silver nanoparticles. J. Biobased. Mater. Bioenergy. 2008, 2, 243-247, https://doi.org/10.1166/jbmb.2008.401.

47. Velusamy, P.; Kumar, G.V.; Jeyanthi, V.; Das, J.; Pachaiappan, R. Bio-inspired green nanoparticles: synthesis, mechanism, and antibacterial application. Toxicol. Res. 2016, 32, 95-102, https://doi.org/10.5487/TR.2016.32.2.095.

48. Zielonka, A.; Klimek-Ochab, M. Fungal synthesis of size defined nanoparticles. Adv. Nat. Sci: Nanosci. Nanotechnol. 2017, 8, https://doi.org/10.1088/2043-6254/aa84d4. 
49. Al-Sharqi, S.A.H. Histological and biometric study of the effects of Fusarium graminarum silver nanoparticles on the kidney in male albino mice. Med. Leg. Update. 2020,20,10281035,https://doi.org/10.37506/mlu.v20i3.1538.

50. Soni, N.; Prakash, S. Efficacy of Fungus Mediated Silver and Gold Nanoparticles Against Aedes Aegypti Larvae. Parasitol. Res. 2012, 110, 175-84, https://doi.org/10.1007/s00436-011-2467-4.

51. Soni, N.; Prakash, S. Entomopathogenic fungus generated Nanoparticles for enhancement of efficacy in Culex quinquefasciatus and Anopheles stephensi. Asian Pacific J. Trop. Dis. 2012, 2, S356-S361, https://doi.org/10.1016/S2222-1808(12)60181-9.

52. Salunkhe, R.B.; Patil, S.V.; Patil, C.D.; Salunke, B.K. Larvicidal potential of silver nanoparticles synthesized using fungus Cochliobolus lunatus against Aedes aegypti (Linnaeus, 1762) and Anopheles stephensi Liston (Diptera; Culicidae). Parasitol. Res. 2011, 109, 823-831, https://doi.org/10.1007/s00436-011-2328-1.

53. Kirthi, A.V.; Rahuman, A.A.; Jayaseelan, C.; Karthik, L.; Marimuthu, S.; Santhoshkumar, T.; Venkatesan, J.; Kim, S.-K.; Kumar, G.; Kumar, S.R.S.; Rao, K.V.B. Novel approach to synthesis silver nanoparticles using plant pathogenic fungi, Puccinia graminis. Materials Letters 2012, 81, 6972,https://doi.org/10.1016/j.matlet.2012.04.103.

54. Willems, van den W. Roadmap report on nanoparticles. Barcelona, Spain: W\&W Espana sl York,2005.

55. Panaceka, A.; Milan, K.; Renata, V.; Robert, P.; Jana, S.; Vladimir, K.; Peter, H.; Radek, Z.; Libor, K. Antifungal activity of silver nanoparticles against Candida spp. Biomatrials. 2009, 30, 6333-6340, https://doi.org/10.1016/j.biomaterials.2009.07.065.

56. Yaqoob, A.A.; Ahmad, H.; Parveen, T.; Ahmad, A.; Oves, M.; Ismail, I.M.I.; Qari, H.A.; Umar, K.; Ibrahim, M.N.M. Recent advances in metal decorated nanomaterials and their various biological applications: A Review. Front. Chem. 2020, 8, https://doi.org/10.3389/fchem.2020.00341.

57. Thakkar, K.N.; Mhatre, S.S.; Parikh, R.Y. Biological synthesis of metallic nanoparticles. Nanomed. 2010, 6, 257-262, https://doi.org/10.1016/j.nano.2009.07.002.

58. Kumar, P.; Shruti, K.; Deshpande, S.; Misra, S. Mosquito Larvicidal and Antimicrobial properties of ethyl acetate crude extracts of Cladosporium Sphaerospermum and Cladosporium macrocarpum. Int. J. Pharma. Biosci. 2016, 7, 451-457.

59. Ranjani, S.; Shariq, A.M.; Adnan, M.; Senthil-Kumar, N.; Ruckmani, K.; Hemalatha, S. Synthesis, characterization and applications of endophytic fungal nanoparticles. Inorg. Nano Metal Chem. 2020,51, 280-287,https://doi.org/10.1080/24701556.2020.1784231.

60. Usman, M.; Farooq, M.; Wakeel, A.; Nawaz, A.; Cheema, S.A.; Rehman, H.U.; Ashraf, I.; Sanaullah, M. Nanotechnology in agriculture: Current status, challenges and future opportunities.Sci.Total.Environ.2020,721,https://doi.org/10.1016/j.scitotenv.2020.137778.

61. Devi, L.S.; Joshi, S.R. Evaluation of the antimicrobial potency of silver nanoparticles biosynthesized by using an endophytic fungus, Cryptosporiopsis ericae PS4. J. microbial. 2014, 52, 667-74, https://doi.org/10.1007/s12275-014-4113-1.

62. Zhaos.; Gorte, R. The activity of Fe-Pd alloys for the water-gas shift reaction catal. Lett. 2004, 92, 75-80, https://doi.org/10.1023/B:CATL.0000011091.57705.6a.

63. Upadhyay, P.K.; Jain, V.K.; Sharma, K.; Sharma, R. Synthesis and applications of ZnO nanoparticles in biomedicine. Res. J. Pharm. Technol. 2020, 13, https://doi.org/10.1080/24701556.2020.1784231.

64. Bérdy, J. Bioactive microbial metabolites. J. Antibiot. 2005, 58, 1-26, https://doi.org/10.1038/ja.2005.1.

65. Gade, A.K.; Bonde, P.; Ingle, A.P.; Marcato, P.D.; Durán, N.; Rai, M.K. Exploitation of Aspergillus niger for synthesis of silver nanoparticles. J. Biobased. Mater. Bioenergy. 2008, 2, 243-247, https://doi.org/10.1166/jbmb.2008.401.

66. Ahluwalia, V.; Kumar, J.; Sisodia, R.; Shakil, N.A.; Walia, S. Green synthesis of silver nanoparticles by Trichoderma harzianum and their bioefficacy evaluation against Staphylococcus aureus and Klebsiella pneumonia. Ind. Crops Prod. 2014, 55, 202-206, https://doi.org/10.1016/j.indcrop.2014.01.026.

67. Khan, N.T.; Khan, M.J.; Jameel, J.; Jameel, N.; Rheman, S.U.A. An overview: biological organisms that serves as nanofactories for metallic nanoparticles synthesis and fungi being the most appropriate. Bioceram. Dev. Appl. 2017, 7.

68. Vahabi, K.; Mansoori, GA.; Karimi, S. Biosynthesis of silver nanoparticles by fungus Trichoderma reesei (A Route for Large-Scale Production of AgNPs). Insci. J. 2011, 1, 65-79, https://doi.org/10.5640/insc.010165.

69. Alghuthaymi, M.A.; Almoammar, H.; Rai, M.; Said-Galiev, E.; Abd-Elsalam, K.A. Myconanoparticles: synthesis and their role in phytopathogens management. Biotechnol. Equip. 2015, 29, 221236,https://doi.org/10.1080/13102818.2015.1008194.

70. Castro-Longoria, E.; Vilchis-Nestor, A.R.; Avalos-Borja, M. Biosynthesis of silver, gold and bimetallic nanoparticles using the filamentous fungus Neurospora crassa. Colloids Surf. B: Biointerfaces2011, 83, 4248, https://doi.org/10.1016/j.colsurfb.2010.10.035.

71. Rajput, S.; Werezuk, R.; Lange, R.M.; Mcdermott, M.T. Fungal isolate optimized for biogenesis of silver nanoparticles with enhanced colloidal stability. Langmuir. 2016, 32, 8688-8697, https://doi.org/10.1021/acs.langmuir.6b01813. 
72. Molnár, Z.; Bódai, V.; Szakacs, G.; Erdélyi, B.; Fogarassy, Z.; Sáfrán, G.; Varga, T.; Kónya, Z.; Tóth-Szeles, E.; Szücs, R.; Lagzi, I. Green synthesis of gold nanoparticles by thermophilic filamentous fungi. Scientific Reports 2018, 8,https://doi.org/10.1038/s41598-018-22112-3.

73. Azmath, P.; Baker, S.; Rakshith, D.; Satish, S. Mycosynthesis of silver nanoparticles bearing antibacterial activity. Saudi Pharm. J. 2016, 24, 140-146, https://doi.org/10.1016/j.jsps.2015.01.008.

74. Sabri, M.A.; Umer, A.; Awan, G.H.; Hassan, M.F.; Hasnain, A. Selection of suitable biological method for the synthesis of silver nanoparticles. Nanomater. Nanotechnol. 2016, 6, 1-20, https://doi.org/10.5772/62644.

75. Costa Silva, L.P.; Oliveira, J.P.; Keijok, W.J.; Silva, A.R.; Aguiar, A.R.; Guimarães, M.C.C.;Ferraz, C.M.; Araújo, J.V.; Tobias, F.L.; Braga, F.R Extracellular biosynthesis of silver nanoparticles using the cell-free filtrate of nematophagus fungus Duddingtonia flagans. Int. J. Nanomed. 2017, 12, 6373-6381, https://doi.org/10.2147/IJN.S137703.

76. Gudikandula, K.; Vadapally, P.; Charya, M.A.S. Biogenic synthesis of silver nanoparticles from white rot fungi: their characterization and antibacterial studies. Open Nano. 2017, 2, 64-78, https://doi.org/10.1016/j.onano.2017.07.002.

77. Ashrafi, S.J.; Rastegar, M.F.; Ashrafi, M.; Yazdian, F.; Pourrahim, R.; Suresh, A.K. Influence of external factors on the production and morphology of biogenic silver nanocrystallites. J. Nanosci. Nanotechnol. 2013, 13, 2295-2301, https://doi.org/10.1166/jnn.2013.6791.

78. Qidwai, A.; Pandey, A.; Kumar, R.; Shukla, S.K.; Dikshit, A. Advances in biogenic nanoparticles and the mechanisms of antimicrobial effects. Indian J. Pharm. Sci. 2018, 80, 592-603, https://doi.org/10.4172/pharmaceutical-sciences.1000398.

79. Yahyaei, B.; Pourali, P. One step conjugation of some chemotherapeutic drugs to the biologically produced gold nanoparticles and assessment of their anticancer effects. Sci. Rep. 2019, 9, https://doi.org/10.1038/s41598-019-46602-0.

80. Vyas, N.; Prakash, S.; Dua, K.K. Metabolites of Metarhizium anisopliae against malaria vectors and nontargeted organisms. Entomal. Omithal. \& Herpetol. 2015, 4,147-149, https://doi.org/10.4172/21610983.1000147.

81. Sharma, V.K.; Yugard, R.A.; Lin, Y. Silver nanoparticles green synthesis and their antimicrobial activities. Adv. Colloid Interf. Sci. 2009, 145, 83-96, https://doi.org/10.1016/j.cis.2008.09.002.

82. Krutyakov, Y.A.; Kudrinskiy, A.A.; Olenin, A.Y.; Lisichkin, G.V. Synthesis and properties of silver nanoparticles advances and prospects. Russian Chem. Reviews. 2008, 77, 233-257, https://doi.org/10.1070/RC2008v077n03ABEH003751.

83. Bekele, E.T.; Gonfa, B.A.; Sabir, F.K. Use of Different Natural Products to Control Growth of Titanium Oxide Nanoparticles in Green Solvent Emulsion, Characterization, and Their Photocatalytic Application. Bioinorg. Chem. Appl.2021, 17, https://doi.org/10.1155/2021/6626313.

84. Arya, S.; Sonawane, H.; Math, S.; Tambade, P.; Chaskar, M.; Shinde, D. Biogenic titanium nanoparticles (TiO2NPs) from Tricoderma citrinoviride extract: synthesis, characterization and antibacterial activity against extremely drug-resistant Pseudomonas aeruginosa. International Nano Letters 2021, 11, 3542,https://doi.org/10.1007/s40089-020-00320-y.

85. Li Sintubin.; Verstraete, W.; Boon, N. Biologically produced Nano silver; Current state and future perspective. Biotechnol. Bioeng. 2012, 109, 2422-2436, https://doi.org/10.1002/bit.24570.

86. Khan, M.R.; Fromm, K.M.; Rizvi, T.F.; Giese, B.; Ahamad, F.; Turner, R.J.; Füeg, M.; Marsili, E. Metal Nanoparticle-Microbe Interactions: Synthesis and Antimicrobial Effects. Part. Part. Syst. Charact. 2020, 37, https://doi.org/10.1002/ppsc.201900419.

87. Kowshik, M.; Vogel, W.; Urban, J.; Kulkarni, S.K.; Paknikar, K.M. Microbial synthesis of semiconductor pbs nanocrystallites. Adv. Mate. 2002, 14, 815-818, https://doi.org/10.1002/15214095(20020605)14:11<815::AID-ADMA815>3.0.CO;2-K.

88. Pavani, K.V.; Sunil Kumar, N.; Sangameswaran, B.B. Synthesis of lead nanoparticles by Aspergillus species. Pol. J. Microbiol. 2012, 61, 61-63, https://doi.org/10.33073/pjm-2012-008.

89. Andreescu, D.; Sau, T.; Goia, D.V. Stabilizer-free nanosized gold sols. J. Colloid Interf. Sci. 2006, 298, 74251, https://doi.org/10.1016/j.jcis.2006.01.011.

90. Pimpang, P.; Choopun, S. Monodispersity and stability of gold nanoparticle stabilized by using polyvinyl alchohol. Chiang Maij Sci. 2011, 38, 31-38.

91. Sanghi, R.; Verma, P.; Puri, S. Enzymatic formation of gold nanoparticles using Phanerochaete chrysoporium. Adv. Chem. Eng. Sci. 2011, 1, 154-162, https://doi.org/10.4236/aces.2011.13023.

92. Das, S.K.; Liang, J.; Schmidt, M.; Laffir, F.; Marsili, E. Biomineralization mechanism of gold by Zygomycete fungi Rhizopous Oryzae. ACS Nano. 2012, 6, 6165-6173, https://doi.org/10.1021/nn301502s.

93. Narayanan, K.B.; Sakthivel, N. Facile green synthesis of gold nanostructures by NADPH-dependent enzyme from the extract of Sclerotium rolfsil. Coll. Surf. A Physicochem. Eng. Asp. 2011, 380, 156-161, https://doi.org/10.1016/j.colsurfa.2011.02.042.

94. Mukherjee, P.; Ahmad, A.; Mandal, D.; Senapati, S.; Sainkar, S.R.; Khan, M.I.; Parishcha, R.; Ajaykumar, P.V.; Alam, M.; Kumar, R.; Sastry, M. Fungus-mediated synthesis of silver nanoparticles and their immobilization in the mycelial matrix; a novel biological approach to nanoparticle synthesis. Nano Lett. 2001, 1, 515-519, https://doi.org/10.1021/n10155274. 
95. Soni, N.; Prakash, S. Synthesis of gold nanoparticles by the fungus Aspergillus niger and its efficacy against mosquito larvae. Report in Parasitol. 2012, 2, 1-7, https://doi.org/10.2147/RIP.S29033.

96. Moraga, E.Q. Entomopathogenic fungi as endophytes: Their broader contribution to IPM and crop production. Biocontrol Sci. Technol. 2020, 1-14. https://doi.org/10.1080/09583157.2020.1771279.

97. Singh, O.V. Bio-nanoparticles, Biosynthesis and sustainable biotechnological implications. USA WileyBlackwell, 2015; pp. 155-186.

98. Majumber, D.R. Bioremediation: Copper nanoparticles from electronic-waste. Inter. J. Engg. Sci. Technol. 2012, 4, 4380-4389.

99. Rai, M.; Bonde, S.; Golinska, P.; Trzci 'nska-Wencel, J.; Gade, A.; Abd-Elsalam, K.A.; Shende, S.; Gaikwad, S.; Ingle, A.P. Fusarium as a Novel Fungus for the Synthesis of Nanoparticles: Mechanism and Applications. J. Fungi. 2021, 7, 139. https://doi.org/10.3390/jof7020139.

100.Pavani, K.V.; Sunil Kumar ,N.; Sangameswaran, B.B. Synthesis of lead nanoparticles by Aspergillus species. Pol. J. Microbiol. 2012, 61, 61-63, https://doi.org/10.33073/pjm-2012-008.

101.Duran, N.; Seabra, A.B. Metallic oxide nanoparticles: State of the art in biogenic synthesis and their mechanism. Appl. Microbiol. Biotechnol. 2010, 95, 275-288, https://doi.org/10.1007/s00253-012-4118-9.

102. Rubilar, O.; Rai, M.; Tortella, G.; Diez, M.C.; Seabra, A.B, Duran, N. Biogenic nanoparticles, copper, copper oxides, copper sulphides, complex copper nanostructures and their applications. Biotechnol. lett. 2013, 135, 1365-1375, https://doi.org/10.1007/s10529-013-1239-x.

103. Husen, A.; Siddiqi, K.S. Plants and microbes assisted Selenium nanoparticles; Characterization and application. J. Nanobiotechnol. 2014, 12, https://doi.org/10.1186/s12951-014-0028-6.

104. Rahimi, J.; Monfared, A.A. Biosynthesis and characterization of silver nanoparticles by Aspergillus Species. Bio. Med. Research International2016, 8, 1-6, https://doi.org/10.1155/2016/5435397.

105.Bharde, A.; Rautaray, D.; Bansal, V.; Ahmad, A.; Sarkar, I.; Yusuf, S.M.; Sanyal, M.; Sastry, M. Extracellular Biosynthesis of Magnetite using Fungi. Small 2006, 2, 135-141, https://doi.org/10.1002/smll.200500180.

106. Khan, NT.; Jameel, N.; Rehman. Optimizing physioculture conditions for the synthesis of silver nanoparticles from Aspergillus niger. J. Nanotechnol. 2016, 7, 421-25, https://doi.org/10.4172/2157-7439.1000402.

107.Vigneshwaran, N.; Kathe, A.A.; Varadarajan, P.V.; Nachane, R.P.; Balasubramanya, R.H. Biomimetics of silver nanoparticles by white rot fungus, Phaenerochaete chrysosporium. Colloids Surf. B: Biointerfaces. 2006, 53, 55-9, https://doi.org/10.1016/j.colsurfb.2006.07.014.

108. Soni, N.; Prakash, S. Synthesis of gold nanoparticles by the fungus Aspergillus niger and its efficacy against mosquito larvae. Report in Parasitol. 2012, 2, 1-7, https://doi.org/10.2147/RIP.S29033.

109. Soni, N.; Prakash, S. Efficacy of Fungus Mediated Silver and Gold Nanoparticles Against Aedes Aegypti Larvae. Parasitol. Res. 2012, 110, 175-84, https://doi.org/10.1007/s00436-011-2467-4.

110. Sweta, B.; Lalit, M.; Srivastava, C.N. Synergistic larvicidal potential of temephos and entomopathogenic fungus, Aspergillus flavus against filarial vector, Culex guinguefaciatus(say). Int. J. Mosq. Res. 2015, 2, 3337.

111. Manimozhi,R.; Anitha. Myco-synthesis of silver nanoparticles using aqueous extract of Aspergillus flavus mycelium and its characterization. Int. J. Pharm. Drug Anal. 2014, 2, 734-739.

112.Vigneshwaran, N.; Ashtaputre, N.; Varadarajan, P.V.; Nachane, R.P.; Paralikar, K.M.; Balasubramanya, R.H. Biological synthesis of silver nanoparticles using the fungus Aspergillus flavus. Materials Letters. 2007, 61, 1413-1418, https://doi.org/10.1016/j.matlet.2006.07.042.

113.Jain, N.; Bhargava, A.; Majumdar, S.; Tarafdar, J.C.; Panwar, J. Extracellular biosynthesis and characterization of silver nanoparticles using Aspergillus flavus NJP08: a mechanism perspective. Nanoscale. 2011, 3, 635-641, https://doi.org/10.1039/c0nr00656d.

114.Souza, G.I.H.; Marcato, P.D.; Duran, N.; Esposito, E. National Meeting of Environmental Microbiology, curtiba. 2004;pp. 55-60.

115.Saravanan, M.; Nanda, A. Extracellular Synthesis of Silver Bionanoparticles from Aspergillus Clavatus and Its Antimicrobial Activity against Mrsa and Mrse. Colloids Surf. B Biointerfaces2010, 77, 214-218, https://doi.org/10.1016/j.colsurfb.2010.01.026.

116. Ratnasri, PV.; Hemalatha, K.P.J. Biological synthesis of silver nanoparticles from Aspergillus fumigatus. Am. J. Adv. Drug Deliv. 2014, 741-751.

117. Rahimi, J.; Monfared, A.A. Biosynthesis and characterization of silver nanoparticles by Aspergillus Species. Bio. Med. Research International2016, 8, 1-6, https://doi.org/10.1155/2016/5435397.

118.Rajan, A.; Cherian, E.; Baskar, G. Biosynthesis Zinc oxide nanoparticles using Aspergillus fumigatus JCF and its antibacterial antibacterial activity. Int. J. Modern Sci. Technol. 2016, 1, 52-57.

119. Shahzad, A.; Saeed, H.; Iqtedar, M.; Hussain, S.Z.; Kaleem, A.; Abdullah, R. Size-controlled production of silver nanoparticles by Aspergillus fumigatus BTCB10: likely antibacterial and cytotoxic effects. J. Nanomater. 2019, 2019, 1-14, https://doi.org/10.1155/2019/5168698.

120.Steinbach, W.J.; Perfect, J.R.; Schell, W.A.; Walsh, T.J.; Benjamin, D.K. In vitro analyses, animal models and 60 clinical cases of invasive Aspergillus terrus infection, Antimicrobe Agents. Chemother. 2004, 48,3217-25,https://doi.org/10.1128/AAC.48.9.3217-3225.2004. 
121.Li, G.; Dan He.; Qian, Y.; Guan, B.; Cui, Y.; Yokoyama, K.; Wang, L. Fungus-mediated green synthesis of silver nanoparticles using Aspergillus terreus. Int. J. Mol. Sci. 2012, 13, 466-476, https://doi.org/10.3390/ijms13010466.

122.Bukhari, T.; Middelman, A.; Koenraadt, C.J.M.; Takken, W.; Knols, B.G.J. Factors affecting fungus-induced larval mortality in Anopheles gambiae and Anopheles stephensi. Malaria J. 2010, 9, 1-15, https://doi.org/10.1186/1475-2875-9-22.

123.Scholte, E.J.; Knols, B.G.J.; Samson, R.A.; Takken, W. Entomopathogenic fungi for mosquito control: a review. J. Insect Sci. 2004, 4, 1-24, https://doi.org/10.1093/jis/4.1.19.

124.Salva, S.; Rashed, Beall, G.W.; Rashad, E.M.; Mostafa, W.A. Control of human filarial vector, Culex quinquefasciatus (diptera: culicidae) through combination of the entomopathogenic fungus, Metarhizium anisopliae and nanoparticles of zinc oxide and aluminum oxide. J. Egypt. Soc. Parasitol.2020,50,221-227, https://doi.org/10.21608/JESP.2020.112999.

125.Ansari, M.A.; Pope, E.C.; Carpenter, S.; Scholte, E.J.; Butt, T.M. Entomopathogenic fungus as a biological control for an important vector of livestock disease: the Culicoides biting midge. PloS one. 2011, 6, https://doi.org/10.1371/journal.pone.0016108.

126. Faria, M.; Wraight, S. Mycoinsecticides and Mycoacaricides: A comprehensive list with worldwide coverage and international classification of formulation types. Bio Control. 2007, 43, 237-256, https://doi.org/10.1016/j.biocontrol.2007.08.001.

127.Hameed, R.S.; Ahmed, S.H.; Nuaman, R.S.; Fayyad, R.J. Synthesis Myconanoparticles by using Metarhizium anisopliae as a biological management for Culex pipiens. Int. J. Biosci. 2018, 12, 323-333, http://dx.doi.org/10.12692/ijb/12.6.323-333.

128.Zimmermann, G.; an Anschutz-Nachr, P.F.L. Bayer Characterization of Metarhizium anisole isolates from Tasmanian pasture soils and their pathogenicity to redheaded cockchafer (Coleoptera: Scarabaeidae: Adoryphorus colony). J. Invert. Pathol. 1997, 69, 285-288.

129.Boomsma, J.J.; Jensen, A.B.; Meyling, N.V. Evolutionary interaction networks of insect pathogenic fungi. Annual Rev. Entomol. 2014, 59, 467-485, https://doi.org/10.1146/annurev-ento-011613-162054.

130.Prabakaran, K.; Ragavendrana, C.; Natarajan, D. Mycosynthesis of silver nanoparticles from Beauveria bassiana and its larvicidal, antibacterial, and cytotoxic effect on human cervical cancer (HeLa) cells. RSC Advance. 2016, 6, 44972-44986, https://doi.org/10.1039/C6RA08593H.

131. Sewify, G.H.; Mabrouk, A.M. The susceptibility of different stages of citrus brown mite Eutetranychus orientalis Oudemans (family: Tetranychidae) to entomopathogenic fungus Verticillium lecanii. Proceedings and abstracts, Vth International Colloquium on Invertebrate Pathology and Microbial Control, Adelaide, Australia, 20-24 August 1990; pp. 395.

132. Andreeva, I.V.; Chternchis, M.V. Microbiologitcheskie preparati protif pautinovo klesha v tiplitsah. Zashita Rastenii1995, 11, 41-42.

133. Schuler, T. Verticillium lecanii (Zimmermann) Viegas (Hyphomycetales: Moniliaceae): Geschichte, Systematik, Verbreitung, Biologie und Anwendung im Pflanzenschutz. Mitteilungen aus der Biologischen Bundesanstalt für Land $u$. Forstwirtschaft, Berlin-Dahlem. Heft1991, 269.

134.Hall, R.A. The Fungus Verticillium lecanii as a Microbial Insecticide against Aphids and Scales. In: Microbial Control of Pests and Plant Diseases1970-1980.Burges, H.D. Editorm Academic Press. 1981a; pp. 483-498.

135. Kamalakannan, S.; Gobinath, C.; Ananth, S. Synthesis and Characterization of Fungus Mediated Silver Nanoparticle for Toxicity on Filarial Vector, Culex quinquefasciatus. Int. J. Pharm. Sci. Rev. Res. 2014, 24, 124-132.

136.Darak, R.; Keerthana, S.L.; Arun Kumar, S, Antibacterial Studies Tabernaemontana divaricata (Apocynaceae) Secondary Metabolites Capped Silver Nanoparticles. Haya:Saudi J. Life Sci. 2018, 3, 551555.

137.Poornima, M.; Jeevan, P.; Prabha, T. Larvicidal Potential of mycosynthesized silver nanoparticles against Culex quinquefasciatus. Indian J. Appl. Microbiol. 2018, 21, 29-38.

138. Amerasan, D.; Nataraj, T.; Murugan, K.; Panneerselvam, C.; Madhiyazhagan, P.; Nicoletti, M.; Benelli, G. Myco-synthesis of silver nanoparticles using Metarhizium anisopliae against the rural malaria vector Anopheles culicifacies Giles (Diptera: Culicidae). J. Pest Sci. 2016, 89, 249-256, https://doi.org/10.1007/s10340-015-0675-x.

139. Govender, Y.; Riddin, T.; Gericke, M.; Whiteley, C.G. Bioreduction of platinum salts into nanoparticles: a mechanistic perspective. Biotechnol. Lett. 2009, 31, 95-100, https://doi.org/10.1007/s10529-008-9825-z.

140.Mishra, A.; Tripathy, S.K.; Wahab, R.; Jeong, S.H.; Hwang, I.; Yang, Y.B.; Kim, Y.S.; Shin, H.S.; Yun, S.H. Microbial synthesis of gold nanoparticles using the fungus Penicillium brevicompactum and their cytotoxic effects against mouse mayo blast cancer 22C12 cells. Appl. Microbiol. Biotechnol. 2011, 92, 617-630, https://doi.org/10.1007/s00253-011-3556-0.

141.Mukherjee, P.; Roy, M.; Mandal, B.; Dey, G.; Mukherjee, P.; Ghatak, J. Green synthesis of highly stabilized nanocrystalline silver particles by a non-pathogenic and agriculturally important fungus T. asperellum. Nanotechnol. 2008, 19, 75103-10, https://doi.org/10.1088/0957-4484/19/7/075103. 
142. Maliszewska, I.; Juraszek, A.; Bielska, K. Green synthesis and characterization of silver nanoparticles using ascomycota fungi Penicillium nalgiovense AJ12. J. Clust. Sci. 2014, 25, 989-1004, https://doi.org/10.1007/s10876-013-0683-z.

143. Soni, N.; Prakash, S. Combinatorial Efficacy of Silver Nanoparticles against Mosquito Larvae. SM J. Nanotechnol. Nanomed. 2016, 1, 1001. 